\title{
Comparison of traditional and agile approach to manage product development projects
}

\author{
Mila Milenković \\ Digital Innovations and Applications \\ Department \\ Telekom Srbija \\ Belgrade, Serbia \\ mila@telekom.rs \\ Ivana Berić \\ Project management department \\ Faculty for Project and Innovative \\ management \\ Belgrade, Serbia \\ ivana.beric@pmc.edu.rs
}

\author{
Bojan Lalić \\ Department of Industrial Engineering \\ and Engineering Management \\ Faculty of Technical Sciences \\ Novi Sad, Serbia \\ blalic@uns.ac.rs \\ Vesna Šobajić \\ Project management department \\ Faculty for Project and Innovative \\ management \\ Belgrade, Serbia \\ vesna.sobajic@pmc.edu.rs
}

\author{
Katarina Pavlović \\ Project management department \\ Faculty for Project and Innovative \\ management \\ Belgrade, Serbia \\ katarina.pavlovic@pmc.edu.rs
}

\begin{abstract}
Telecommunications have become highly important for the successful business operations of almost every organization in the world, in the public and private sector, and is the core of most multinational companies' businesses. Telecommunications are an integral part of the global communications network; they are critical for organizations as well as for individuals and have socio-economic value. Large telecommunication companies are doing business in an environment where there is a discrepancy between the need for the introduction of innovations into the portfolio of services and the traditional methods of service development, as well as their market placement. With the expansion of the internet in the industry, the ways of distribution and consumption of digital services have changed considerably. Taking into consideration the increasing complexity of regulations and the environment in which projects that support the development of ICT products and services are led, the right choice of project management methodology is becoming more important. Alongside with the usage of traditional approaches to project management, there is a development of new methodologies through the introduction of dynamic models for achieving project results more quickly. This thesis is based on research conducted on a telecommunications company representative in the region, with the assumption that the introduction of agile methodologies can achieve competitiveness in the highly competitive market of modern telecommunications services. The presented results are based on research conducted in the large telecommunications company, with an emphasis on the recognition of requirements for the introduction of different project management methodologies in the service development process. Based on surveys of management and employees of the company that is involved in the process of service development, test and agile management have been introduced along with the existing traditional management. This paper shows a comparison between these two methodologies on one project which includes the introduction of an innovative ICT service. Based on the results, the hypothesis which assumes that the introduction of agile management provides competitiveness on the market of telecommunications services has been confirmed.
\end{abstract}

Keywords-Traditional, Agile, Project Management methodologies, telecommunications, innovations, ICT services

\section{INTRODUCTION}

\section{A. The main characteristics of the telecommunications market}

The telecommunications industry is the fifthlargest industry in the world and continues to grow at a global level [1]. We are witnessing huge investments in the ICT sector, especially in the area of mobile telecommunication networks. Telecommunication products have characteristics similar to the services sector [2]: intangibleness - information that is transmitted can't be seen or touched. Capacity can't be allocated for future usage, and unused bandwidth means loss of profit [3].

Telecommunications also remind us of the manufacturing industry because they demand large investments into the development, maintenance, and reconstruction of this infrastructure [4]. The telecommunications industry can be defined as an industry of services that intensively employs high technology systems. This definition allows the telecommunications industry to differentiate itself from other industries and to show the specifics of the projects that develop new products.

The cooperation plus competitiveness with the partner industries are leading towards the term coopetition [5], that is, the way that characterizes business in the telecommunication industry, introducing an innovative business model, based on revenue share in the value chain.

\section{B. Providing competitiveness in the service offering through vertical integration}

The telecommunications ecosystem is an open and dynamic system, and it is creating the possibilities for joining the activities with additional values for all players on the market. The strategic goal of new 
players on the telecommunications market is to enable their entrance on the future market of mobile ICT services and in such a way to have leading positions in the ecosystem and with their innovations and the possibility of rapid services development an advantage. With the goal to enable an adequate business concept, companies are in the process of corporate restructuring [6], to change the structure and the level of engaged assets in the company.

The strategy of connecting organizations through the creation of partnerships, networks or alliances is becoming inevitable. To successfully adjust to the changes, companies are opening towards other entities in the industry as well as towards competitor companies [7]. The focus is on savings of resources, information access and the acquirement of new skills with the preservation of information that represents business secrets. In this way, the organization becomes more competitive on the global market than by relying on its own resources [8]. Connectivity and cooperation between organizations is not an invention, but a basic characteristic of these relationships is the achievement of a high level of independence and the establishment of short-term cooperation [9].

Information technologies (IT) have established the conditions for the establishment of solid connections between organizations, through the creation of centres for mutual services. Managers of the companies in the recent years have been motivated to develop a new strategy for growth and development, and several companies have restructured [10] and redesigned their internal organization through the redefinition of their processes. Additionally, inter-organizational relationships represent effective, new strategies for resource concentration to increase the competitiveness of the members and successfully doing business on the market [11]

The companies have initially interpolated many of the value chain processes through vertical integration and development or affiliation of jobs that are complementary, to the basic business through diversification [12]. However, internalization has not been implemented at the same degree or in the same way with all the companies, as an example American companies that aspired towards greater internalization in comparison to the other European rival companies [13]. To support externalization, there has been a concentration of resources at the regional level so that large companies could rely on other smaller companies in the process of acquiring input [14].

\section{Open innovations - development of services concept}

The term "open innovations" (Open innovations OI) has been introduced by professor $\mathrm{H}$. Chesbrough, director of the faculty's Center for Open Innovation at the University of California. This term defines the usage of intake and outtake of knowledge to improve internal innovations and expand the markets form external exploitation of innovations [15]. Open innovations offer different ways for ideas to be offered on the market, and one way is through the development of partner cooperation with external companies or through cooperation of manufacturers and clients initiated by the company to achieve added value to the customer, co-creation [16].

Introduction of open innovations creates the need for project development with external companies that on the interfaces requires a need for synchronization of speed and methods of development and more complex stakeholder management. A project manager has a role as coordinator and entrepreneur in the company, and the methodology of project management requires movement from traditional towards agile approach by a larger company. Smaller companies are creators of ideas and innovations and as a rule use agile methodologies of project management [17].

Agile project management is a characteristic of small organizations that have solutions structured around open innovations [18, 19]. Hybrid project management, depending on the type and scale of the project, involves cooperation between a large company that has a developed market with several companies that are competing for the market and offer innovative solutions [20].

Considering that in the company projects for incorporation of innovations are led in parallel with other projects for development of services and products, that can be platform projects or derived from project [21], and which can bid for the same resources within the company, the need for usage of project portfolio is recognized so that real selection of projects for integration of innovations can be made, where organization can use available resources in the best way and extend the existing market or create new markets for the implementation of new technologies [22].

In relation to project management, the new approach to project management, differing from the traditional, has been created as an aspiration for constant innovations and need for cost-cutting. It is based on several principles: constant innovation, product adjustment, delivery time reduction, adjustment of people and processes, reliable results, new agile approach to project management characterized by its ability to respond to change resulting in project gain [23]

Gassmann and Enkel (2006) [24] have proposed the environment that includes three central archetypes for open innovations that are shown in Fig. 1 that includes: Outside-in process, Inside-out process, and Coupled process.

This environment provides useful insight for presenting the usage of open innovations in a multiproject agile environment and challenges and 


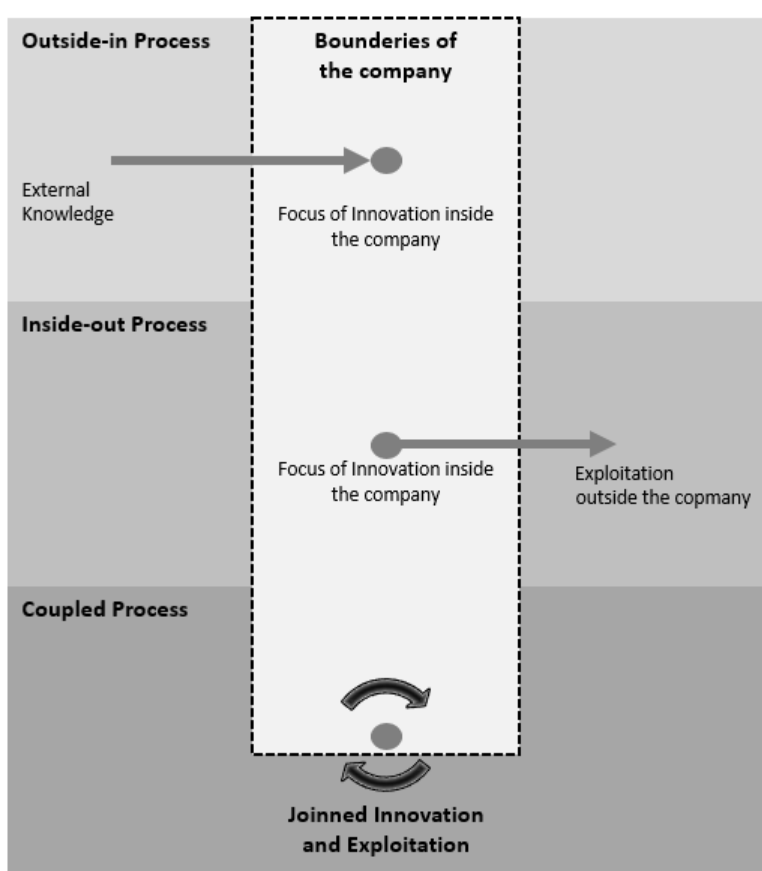

Fig. 1. The environment for open innovation [25]

Consequences of this approach of project management [26]. Previous research papers focused on the way of management of open innovations in large companies, mainly considered the perspective of organization of a large company and its process management. Later in the articles concerning project management of open innovations have started to be issued [15].

\section{PROBLEM AND OBJECTIVE OF THE RESEARCH}

The rapid changes in the dynamic telecommunications market leave no more room for lack of integration and communication among decentralized development teams in a large organization than for the lack of good interfaces among modules in a modular system.

The complexity of projects that introduce new innovative services force organizations to improve their criteria for the identification and selection of the appropriate project methodology and management of the project itself requires a higher degree of flexibility, precisely because of frequent changes in stakeholders demands. As the complexity of projects increases, this increases the scope of possible changes within them, especially in the field of information technology. These changes can occur at any stage of the life cycle of a project, and revisions of the initial plan and adaptations to emerging circumstances as well as the provision of rapid decision-making mechanisms is the ultimate condition for the success of future projects.

The traditional approach to project management implies a methodology based on a detailed project plan, from which the implementation can start, such as PMI, IPMA, and PRINCE2. Unlike the traditional approach, in agile methodologies planning is done in iterations. The use of Agile project management methodologies has expanded greatly in the last ten years since the creation of the Agile Manifesto document in 2001 [27]. Agile project management is present in small teams that are guided by the principles of delivering results incrementally, along with an increase in innovative product features, prioritization of work according to needs and iterative implementation of the project according to the user's vision and feedback. Some of the most important agile methodologies are SCRUM, Extreme Programming (XP), the Crystal Family, EVO, and the Dynamic Systems Development Method (DSDM).

The main differences between the aforementioned project methodology and traditional project management refer to the degree of risk, the number of stakeholders in the management model and the duration of projects [25].

Given the increasing complexity of the frameworks and environments under which projects that support the development of services and products will be led, the significance of the proper selection of an applied project management methodology becomes ever clearer.

\section{A. The aim of the research paper}

The aim of this research paper is to show that the traditional methods of project management that are present in large companies do not support the competitiveness of these companies in a dynamic and rising ICT market in the right way, and that the choice of project management methodologies needs to be adjusted to achieve flexibility and rapid adaptation to changes in the market.

Because of this, a need to find a way to overcome the challenges facing large telecommunication companies and to find a solution through the application of different project methodologies was recognized, based on the research conducted on the experience of a large referential telecommunication company, the results of which may apply to other companies in this field, as well as other organizations that have the need both to introduce innovation into their portfolio of services and agility in project management, in parallel with the traditional model of project management, already present in the organization.

\section{B. The subject of the research}

The subject in this paper is the selection of efficient project management models for the implementation of development projects for the introduction of innovations in the portfolio of companies, in order to achieve the flexibility and speed of response that is necessary for success in the business. The aim of the paper is to establish an adequate model for managing development projects, which should ensure agility, as well as compliance with the strategic management of the company. Project management had the goal of realizing activities in the right way, and agile management searched for the right way at the right time [25]. 
The basic research problem is finding adequate project support for accelerated development in the telecommunications market in large corporations, with the aim of introducing innovative products and services into their portfolio. This implies that large companies with established methods of managing projects should cooperate with smaller, agile companies, which implies adopting their way of thinking, changing corporate culture, speeding up responses to business change needs on interfaces with smaller companies. In order to respond to these new demands, a company will inevitably have to introduce new skills and project management tools that a large company does not support.

In accordance with the defined problem and the set objectives of the research, the following hypothesis can be defined:

H1 The introduction of agile project management increases the competitiveness of a large corporate company in the telecommunications services development market

\section{CONDUCTING THE RESEARCH}

\section{A. Representativity of the selected company}

A survey related to the introduction of innovations into the portfolio of the products and services of a company was carried out in accordance with the recommendations laid out by the OECD (2005) which suggests that, concerning the relationship between innovative research and the organization of activities, the most suitable statistical unit for research is - a company. The representative telecommunication company was chosen because it is the market and regional leader [28]. It is an organizational, technological, marketing and sales-wise match with all similar companies in the telecommunications industry. The company has implemented traditional project management in the process of developing the company's services and products, and its strategic goal is defined as the introduction of new innovative services and products, so there is a high level of motivation to undertake analysis in this area with the aim of introducing adequate tools.

\section{B. Methods of the research}

The descriptive method was used in the research, including the collection, processing, presentation and interpretation of data, as well as forming a conclusion based on the obtained results.

Interviews and questionnaires - The survey was conducted in two ways: direct, verbal interviews and indirect written research based on the questionnaire (attached to the paper), which was the most suitable instrument for this type of research problem with predefined issues.

The interviews were conducted with top managers of the company in order to get as high-quality responses to open questions. Mid-level managers and their employees filled out surveys. All managers were selected, taking into account that the organizational unit they were leading took part in the process of developing services within the company.

\section{Respondents:}

The largest percentage of respondents are employed in the field of service development, followed by the IT/ICT field, and finally, project management and service management.

The response rate is as follows:

$62 \%$ for middle and high management level (managers and heads of a sector), 13 out of 21 selected managers answered of 61

$52 \%$ for employees, 32 participants answered out

The display of the number of respondents among management using some of the project management methodologies and the scope of their use is shown in Fig. 2.

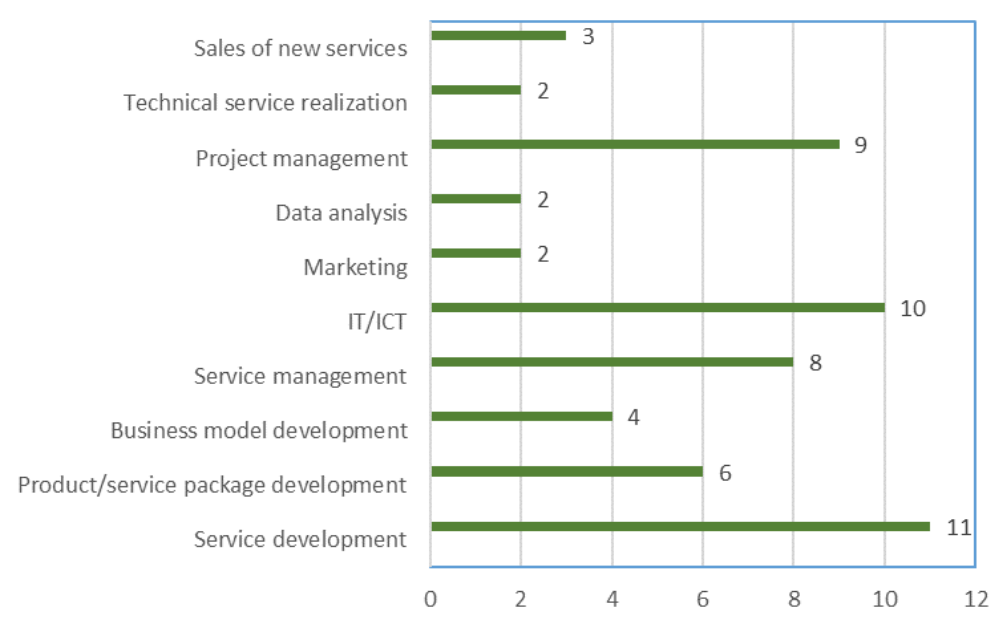

Fig. 2. The number of respondents 


\section{Validation of the questionnaire}

In order to validate the questionnaire (Pilot Study), a survey was conducted first by partnering companies that cooperate with a large representative company in the process of development of services and whose portfolio represents a strategic fit with the services of the representative company. The offered answers in the questions of the survey were confirmed, and elements that were difficult to understand were identified. Simplification and clarification of the offered answers in the closed questions were also carried out. These partnering companies have already introduced an agile project approach in their development, sales and business units.

\section{RESULTS OF THE RESEARCH IN THE MANAGEMENT PART OF THE REPRESENTATIVE COMPANY}

According to a survey conducted by 12 world companies in the ICT sector for measuring the performance of research work of companies and their ecosystems, six elements were chosen as significant indicators for the development of services [29]. Respondents prioritized the introduction of new services into the portfolio of the company among offered six indicators, as shown in Table I:

In addition to the security aspect and compliance with regulatory regulations, management has given priority to the criteria evidenced in Table II on the basis of which priority can be given to projects in the field of development of services.

The chosen criteria are based on the commercial and business metric defined by Geisler [30].

The majority of respondents chosen prioritization of projects as the key criteria for increasing the efficiency of development projects. All the management choices related to key challenges are shown in Fig. 3.

For improving the utilization of human resources, the important things are interpersonal consultation and communication and external competence, as can been seen in Fig. 4

From the given answers related to the key indicators for achieving innovation of the products and services of the company, the management estimated that the most important is the product or service is not to be offered by the competition (Fig. 5):

Most respondents believe that the iterative project management process would be useful during the entire project.

The biggest advantage of the traditional approach to project management according to the research of management responses is the distribution of work according to the defined plan and the availability of resources.

When it comes to the agile approach to project management, the biggest advantage is in adapting the team to new requirements and changes.

\section{RESULTS OF THE SURVEY OF EMPLOYEES}

Out of the six elements that are significant for the development of services, the surveyed employees gave priority to "Entering a new market". Other elements are given in Table III by importance.

The largest number of respondents has chosen agility in decision making as a key criterion for increasing the efficiency of development projects. All

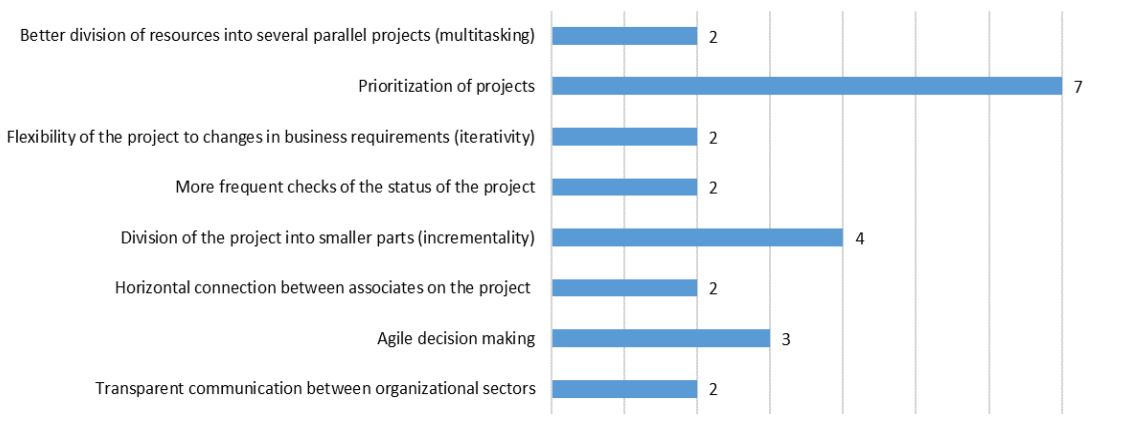

Fig. 3. Key criteria for increasing the efficiency of development projects

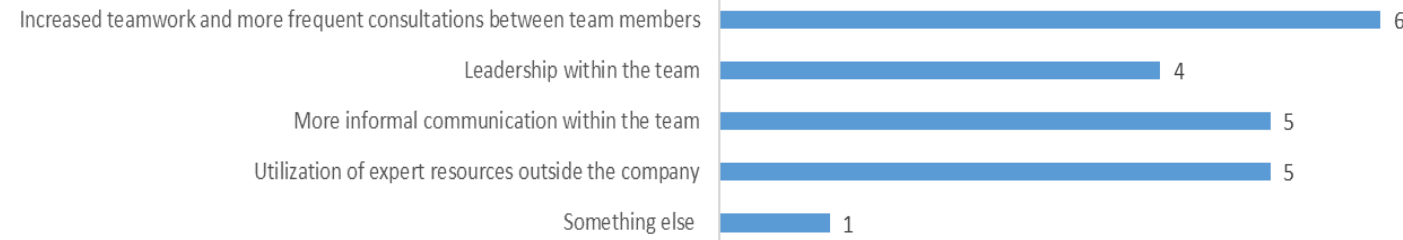

Fig. 4. Improving the utilization of human resources 
Offering products or services through business cooperation with third parties, who have expertise in a particular field

Offering products or services in areas that are not the main business activities of the company

Offering products or services that are technologically

The product or service is more economically efficient than similar products or services of competing companies

The product or service is not offered by competing companies

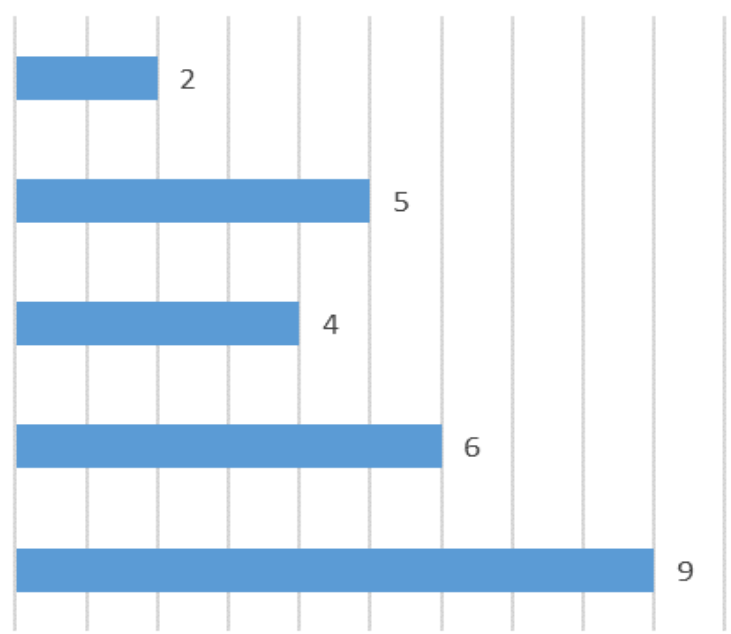

Fig 5. Key indicators for achieving innovation in a company's products and services
Both groups of the respondents - managers and employees agreed on majority of chosen answers by giving priority to the answer that product or service is not offered by competition and that offering of products and services from the offered six indicators. Employees gave higher score to the technological advantage to the competitors, as it is shown in Fig. 7.

Both managers and employees pointed to the interpersonal skills of the team members. Additionally, employees recognized leadership as an important factor for the improvement of the utilization of human resources.

TABLE I. ELEMENTS SIGNIFICANT FOR SERVICE DEVELOPMENT [29]

\begin{tabular}{|l|l|}
\hline 1 & Introduction of a new service into the portfolio of the company \\
\hline 2 & Introduction of new technologies \\
\hline 3 & Entering a new market \\
\hline 4 & Innovative business models \\
\hline 5 & Creation of a new product/service package \\
\hline 6 & Improvements to existing services \\
\hline
\end{tabular}
respondents) is in adapting the team to new demands and changes.
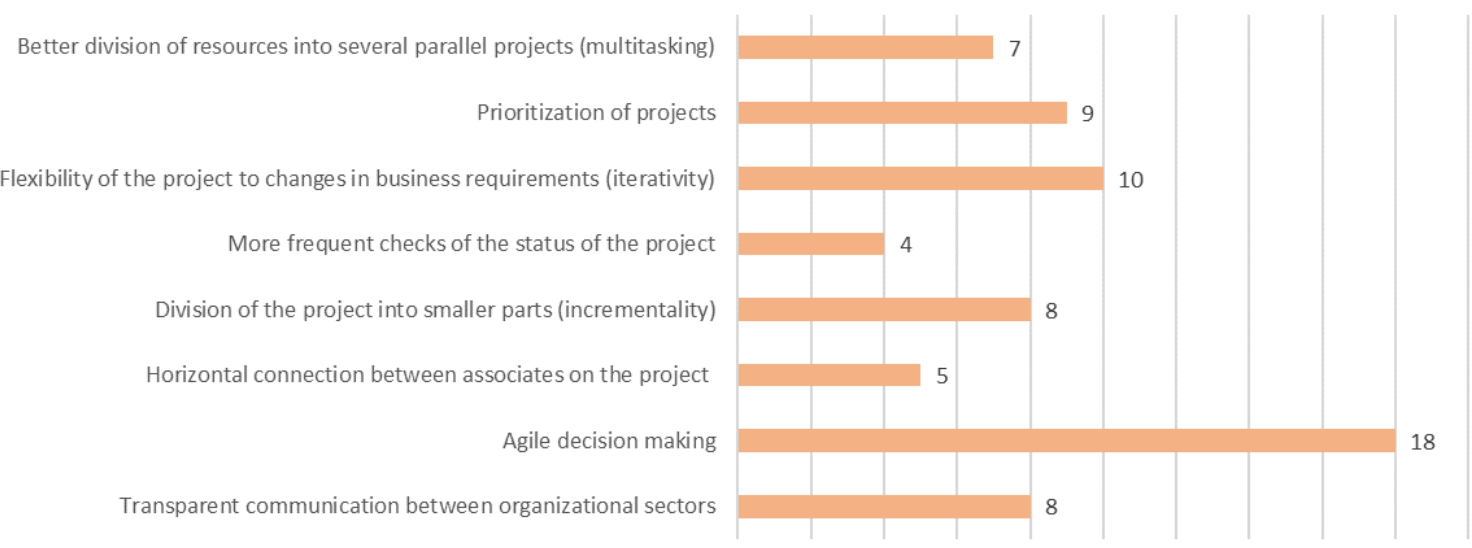

Fig. 6. Key criteria for increasing the efficiency of development projects 


\author{
Offering products or services through \\ business cooperation with third parties, who \\ have expertise in a particular field \\ Offering products or services in areas that are \\ not the main business activities of the \\ company \\ Offering products or services that are \\ technologically more advanced than their \\ competitors \\ The product or service is more economically \\ efficient than similar products or services of \\ competing companies \\ The product or service is not offered by \\ competing companies
}

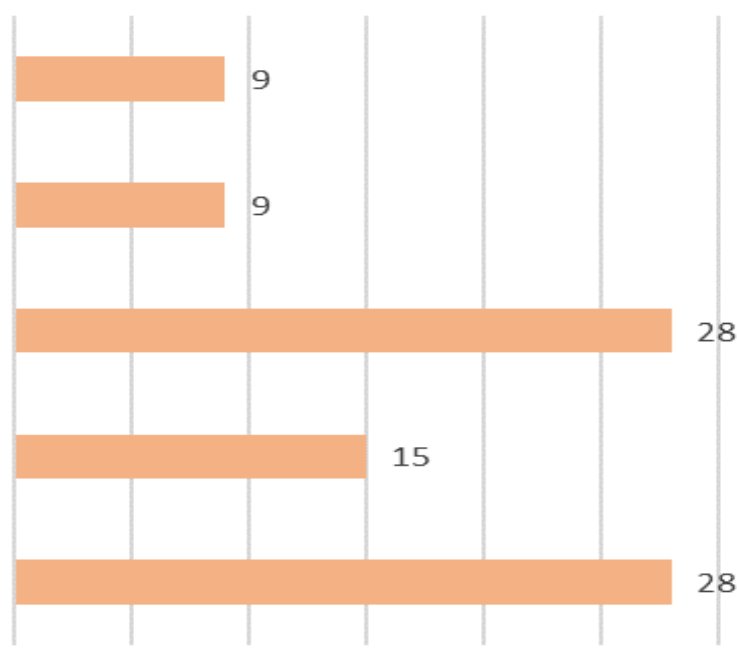

Fig. 7. Key indicators for achieving innovation in company products and services - employees

Interviewed managers and surveyed employees recognized in similar ways advantages of two compared project management methodologies traditional vs agile. They agreed upon necessity of usage Agile project management additionally to the existing traditional way of managing the projects. Most of them believe that the iterative project management process would be useful throughout the entire project. The only difference between these two groups is in understanding which of the key criteria for increasing the efficiency of development projects is the most important: managers think this is the prioritization of the projects and employees believe that agility of decision making is the most important to gain efficiency.

TABLE II. CRITERIA - PRIORITIZATION OF PROJECTS IN THE FIELD OF SERVICE DEVELOPMENT [30]

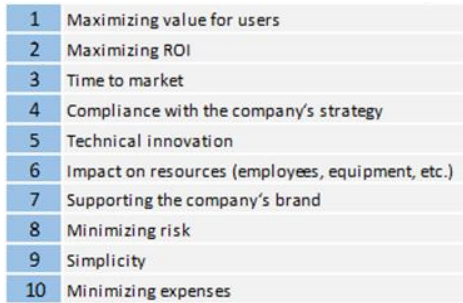

As a result of a survey, it was recognized that it is necessary to have iterative and incremental way of managing the projects, better teamwork based on more informal communications and higher adaptation of the team to requirements and changes throughout the project, as well as agile decision making.

\section{COMPARISON OF TRADITIONAL AND AGILE MANAGEMENT ON A SPECIFIC PROJECT}

In order to compare the traditional and agile methodology of project management, the implementation of both methods was carried out on a concrete project within a selected representative telecommunication company on which the research was carried out. A comparison was made on the ICT service that has part of the equipment and part of the software application.

\section{A. Traditional project management}

In the case of a traditional model of project management had to include the following phases: the phase of specification and analysis of requests - for collecting and documenting requests in order to determine all the functionalities that the product should have and a document specifying software requirements was created (Software Requirement Specification - SRS); phase of building product design - entry into this phase is a document from the previous phase, and the phase itself includes defining scope of the work to be done (high-level design); the integration and testing phase of the system - includes effective system testing to ensure better product quality and get reliable results and a maintenance phase in order to optimize the product through corrections, add new or remove unnecessary functionality (Fig. 8).

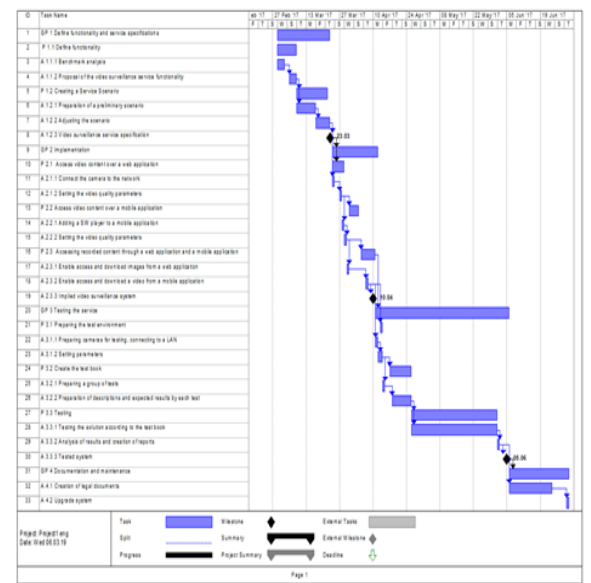

Fig. 8. Traditional project management 


\section{B. Agile project management}

The agile project management method was then applied to the development project of the same service. Unlike the traditional, agile method is a combination of iterative and incremental process models, taking into account the flexibility and timely delivery of the product. The product develops iteratively, each iteration usually lasts from 2 to 3 weeks, and includes performing a range of tasks starting from the collection of requests, planning, design, coding, and testing. Each subsequent iteration guarantees the improvement of product functionality as opposed to the previous one, and during the last iteration, the product itself has all the functionality required by the user.

Considering that user's requirements are susceptible to change, service-oriented and software projects have a need for a mechanism that will provide controlled modifications of the request, as well as that the mechanism of change of the request is more agile and more flexible than the one that is defined in terms of managing changes in projects that are conducted in a traditional manner. Because of its advantages in terms of simpler adaptation to changes, interaction with users during the project, which contributes to a better understanding of the user's expectations related to the end product and allowing the product to be available at an early stage. Simplified, the difference between traditional and agile project management methodology applied to the same project is shown in Fig. 9 (Satpathy, 2016)

\section{DISCUSSION AND PROOF OF THE HYPOTHESIS}

Based on the conducted testing of traditional methodology and agile methodology on the same ICT service development project, it has been demonstrated that in the case of the agile methodology the first version of the product was launched earlier to the customers. Users were allowed to influence the further development of the service through the subsequent versions of the software part of the service, although the equipment itself remained the same for the users.

This enabled faster market entry, shorter Time-toMarket and the possibility of incremental and iterative development of the same service which in traditional project management required much more complex prior analysis and planning, and the phases of the project went one after the other on a waterfall way, which extended the deadline for the first launch of the product on the market and prevented interaction with the users at the stage of service development.

Based on the conducted research and testing, through the analysis of the results, it was concluded that in addition to the traditional way of managing projects, agile methodologies need to be introduced to

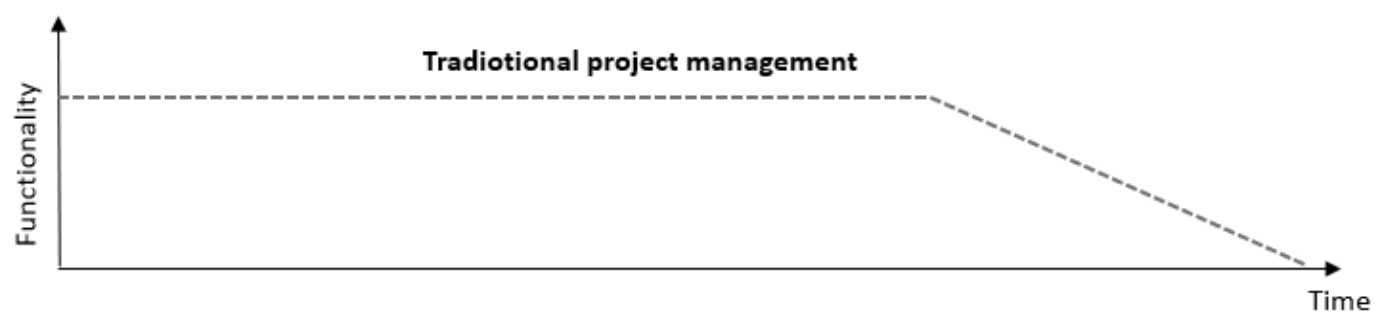

\begin{tabular}{|l|l|l|l|l|}
\hline $\begin{array}{l}\text { Reguest } \\
\text { analysis }\end{array}$ & Design & Implementation & Testing & Maintenance \\
\hline
\end{tabular}
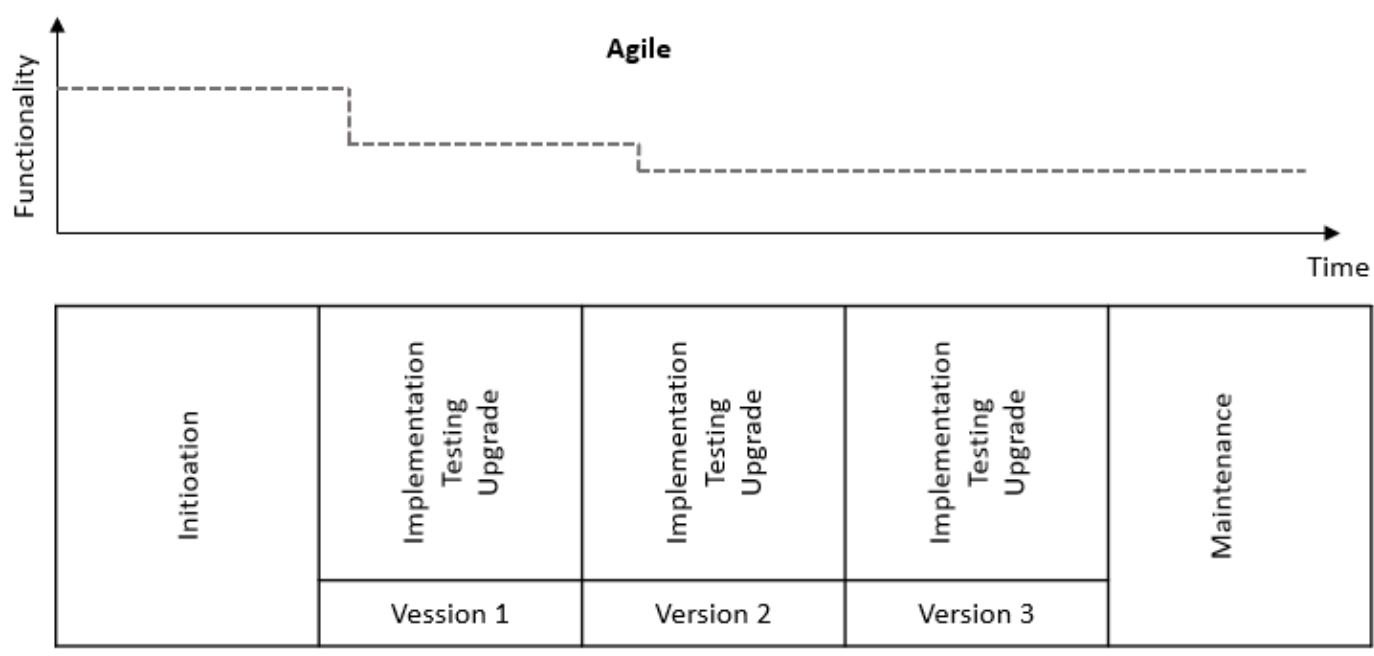

Fig. 9. Comparison of the traditional and agile way of managing on a particular project (Satpathy, 2016) 
offer additional benefits for the efficient development of services, through early engagement of users during initial testing, focused engineering, improved cooperation, risk-taking at the very beginning, and consistency [31].

Because of all of the above, the application of agile management is the most effective when the requirements are not clearly defined in the beginning, and their change is expected in further stages, when the product needs to be developed in a short period of time or when a prototype with certain functionalities is required before the final product. Based on the conducted research, through the testing of the introduction of agile project management on an innovative ICT project, it has been demonstrated that the introduction of agile project management increases the competitiveness of a large corporate company on the market of development of telecommunications services, which was the starting hypothesis of this work.

\section{VIII.FUTURE DIRECTIONS OF RESEARCH}

Future research could focus on the trend of digital transformation and the different areas of digitization of services and processes, in which an agile approach to projects could be applied. There is a need to change the development of new services and products based on agile approach and the introduction of an even greater level of using open innovations caused by the huge growth in the use of smart devices, high-speed data transfer latest technological advances such as artificial intelligence (artificial intelligence), selftaught machines (machine learning), IoT concepts (internet of things) and data processing through the Big Data. Further research is proposed in the direction of linking agile transformation in the telecommunications industry with the goal of offering as many ICT services and services as possible. Agile transformation should properly support the process of digital transformation and the introduction of innovations as a prerequisite for further progress of society.

\section{CONCLUSION}

The latest trend in project management represents the synergy of traditional and agile project management methodologies and an important direction for the development of project management, especially in the ICT industry and information society. Significant progress is expected in terms of integrating different project methodologies for the needs of modern business.

Regional accelerated development requires large companies ready for quick reaction to the market and introducing innovations in their own portfolio, with the goal of aligning with inevitable rapid changes in the industry and society as a whole, and their speed of introduction represents a new challenge in the required models and the associated project management methodology. Project management can be interpreted as a tool for initiation the development of innovation, and the appropriately applied project methodology requires it to be supported through the development of information technologies in a way to provide a framework for rapid decision-making. The area of project management is still intensively developing, and in the development, the goal is flexibility and compliance with possible project needs in the future.

\section{REFERENCES}

[1] "TechnoFunc Domain \& Industry Knowledge," 2016. [Online]. Available: http://www.technofunc.com/index.php/domainknowledge/telecom-industry/item/overview-of-telecom-sector.

[2] P. Kotler, V. Wong, J. Saunders and G. Armstrong, Principles of Marketing - Fourth European Edition, Harlow: Pearson Education Limited , 2005.

[3] M. Kosaroglu and R. A. Hunt, "New Product Development Project Manager Skill Sets. in the Telecommunications Industry," $4 \quad 62016 . \quad$ [Online]. Available: http://docplayer.net/15911350-New-product-developmentproject-manager-skill-sets-in-the-telecommunicationsindustry.html.

[4] L. Robertson and C. Jones, "Application of lean production and agile manufacturing concepts in a telecommunications environment," International Journal of Agile Management Systems, 1999.

[5] "Implementing Strategy in the Telecom Industry," 1162016. [Online]. Available: http://www.mce-ama.com/industryexpertise/telecom/\#top.

[6] M. Todorović, Poslovno i finansijsko restrukturiranje preduzeća, Beograd: Savez računovođa i revizora Beograd, 2010.

[7] J. Schermehorn, J. Hunt and R. Osborn, "Organizational Behaviour," John Wiley, 2005.

[8] M. Porter, "Competitive Advantage: Creating and Sustaining Superior Performance," The Free Press, New York, 1985.

[9] M. Joel, Podolny and L. Karen, "Network forms of organization," Rev. Sociol. 24, pp. 57-76, 1998.

[10] C. Handy, "Trust and the Virtual Organization," Harvard Business Review, 1995.

[11] M. Delgado, M. Porter and S. Scott, "Clusters and Entrepreneurship," 2010.

[12] A. D. Chandler, "The Visible Hand: The Managerial Revolution in American Business," Harvard University Press, 1997.

[13] C. Snow, R. Miles and H. Coleman, "Managing 2st Century Network Organizations," Organizational Dynamics Vol 20, Issue 3, 1992

[14] J. Zeitlin, "Industrial districts and regional clusters," The Oxford University Press, Oxford, 2007.

[15] H. Chesbrouh and S. Brunswicker, "Managing open innovation in large firms," Fraunhofer Verlag, Stuttgart, 2013.

[16] S. Gajic, M. Jovanovic, B. Lalic, A. Sladic and S. Moraca, "Project Management methods for stimulating co-creation in IT projects," Conference Paper, Novi Sad, 2014.

[17] F. Cococcioni and L. De Giudici, "Exploring Project Management in Open Innovation," Master of Science Thesis, Gothenburg, 2014.

[18] K. Power, L. Morgan and K. Conboy , Enabling Open Innovation through Agile Development, Trondheim: University of Limerick, 2010.

[19] T. Dingšryr, T. Dybl and N. B. Moe, Agile Software Development: Current Research and Future Directions, Berlin/Heidelberg: Springer, 2010.

[20] M. Rahmanian, "A Comparative Study on Hybrid IT Project Management," International Journal of Computer and 
Information Technology V3, 2014.

[21] B. Lalić, "Doktorska disertacija - Prilog istraživanju uslova za razvoj inteligentnih preduzeća," Univerzitet u Novom Sadu, Fakultet tehničkih nauka, Novi Sad-Hoboken-MariborMarkovac, 2011.

[22] V. Mandić, V. Rašić, J. Jevtović, T. Knežević, L. Subašić and D. Z. Šutić, "Metodologija za upravljanje inovacijama," Univerzitet u Kragujevcu, Kragujevac, 2014.

[23] The Association for Project Management, "The Practical Adoption of Agile Methodologies," 2015. [Online]. Available: https://www.apm.org.uk/sites/default/files/The-PracticalAdoption-of-Agile-Methodologies.pdf.

[24] O. Gassmann and E. Enkel, "Constituents of Open Innovation: Three Core Process Archetypes," R\&D Management, 2006.

[25] B. Lalic, M. Jovanovic, S. Gajic, N. Kurucki and S. Moraca, "Future Challenges in project management," Daaam International, Vienna, 2013.

[26] K. Conboy and L. Morgan, "Combining open innovation and agile approaches: implications for is project managers (research-in-progress)," University of Limerick, Ireland.

[27] K. Beck, M. Beedle, A. Bennekum, A. Cockburn, W. Cunningham and M. Fowler, "Manifesto for Agile Software Development," www.agilemanifesto.org, 2001.

[28] RATEL, "Pregled tržišta telekomunikacija i poštanskih usluga u Republici Srbiji u 2016. godini," RATEL, Beograd, 2016.

[29] T. Samsonowa, Industrial Research Performance Management - Key Performance Indicators in the ICT industry, Berlin: Springer Heidelberg Dordrecht London, 2012.

[30] E. Geisler, The metrics of science and technology, Westport: Quorum Books, 2000.

[31] PwC, "Accelerating embedded software development via agile techniques," PricewaterhouseCoopers LLP - Technology Institute, 2013. 